\title{
Strategi Ulama Dayah dalam Penangkalan Radikalisme pada Kalangan Santri
}

\author{
Jon Paisal ${ }^{* 1}$, Hasnadi ${ }^{2}$, Anwar ${ }^{3}$ \\ STAIN Teungku Dirundeng Meulaboh, Aceh ${ }^{1,2,3}$ \\ E-mail: jonpaisal2@gmail.com*1, hasnadi@staindirundeng.ac.id ${ }^{2}$, \\ anwar@staindirundeng.ac.id ${ }^{3}$
}

\begin{abstract}
The act of radicalism resulted in cases of terrorism in the name of religion so that it had an impact on social life in society. The role of the ulama is very important to anticipate that radical ideas and terrorism do not develop in society. This study aims to find out the strategy of the dayah ulama in countering radicalism among students in Aceh Jaya district through a qualitative descriptive approach. Data collection techniques through observation, interviews, and documentation. The results of this study indicate that the strategy to counter radicalism carried out by the dayah ulama is to convey da'wah which includes material on national insight delivered to students, da'wah about love for the homeland, cooperating with the TNI and Polri, habituation of exemplary attitudes, religious studies through recitations, activities of memorizing the Qur'an and recitation of books and carrying out religious activities in the dayah. The results of this study can be used as knowledge, information and comparisons for other institutions as an alternative step in the context of eradicating radicalism in Indonesia.
\end{abstract}

Keywords: Strategies of Ulama, Dayah, Countering Radicalism, and Santri.

\begin{abstract}
Abstrak
Tindakan radikalisme mengakibatkan adanya kasus terorisme yang mengatasnamakan agama sehingga berdampak pada kehidupan sosial dalam masyarakat. Peran ulama sangat penting untuk mengantisipasi agar paham-paham radikal dan terorisme tidak berkembang dalam masayarakat. Penelitian ini bertujuan untuk mengatahui strategi ulama dayah dalam menangkal radikalisme pada kalangan santri di kabupaten Aceh Jaya melalui pendekatan deskriptif kualitatif. Teknik pengumpulan data melalui observasi, wawancara, dan dokumentasi. Hasil penelitian ini menunjukan bahwa strategi penangkalan radikalisme yang dilakukan oleh ulama dayah yaitu menyampaikan dakwah yang meliputi materi wawasan kebangsaan yang disampaikan kepada santri, dakwah tentang rasa
\end{abstract}


cinta tanah air, melakukan kerjasama dengan TNI dan Polri, pembiasaan sikap keteladanan, kajian-kajian agama melalui pengajian, kegiatan menghafal Al-Qur'an dan pengajian kitab dan melakukan kegiatan-kegiatan keagamaan di dayah. Hasil penelitian ini dapat dijadikan sebagai pengetahuan, informasi dan pembanding bagi lembaga-lembaga lainnya sebagai langkah alternatif dalam rangka pemberantasan radikalisme di Indonesia.

Kata Kunci: Strategi Ulama, Dayah, Penangkalan, Radikalisme, dan Santri.

\section{PENDAHULUAN}

Sebuah tragedi yang menimpa warga Syiah dan Ahmadiyah ketika konflik agama yang kiat terjadi dan menodai keharmonisan kehidupan umat keberagamaan, tindakan radikalisme tersebut terjadi begitu kejam yang berlangsung pada konflik antar etnis dan antar umat beragama, seperti Pontianak, Poso, Sampit dan Ambon. Selanjutnya pada beberapa tahun terakhir, beredar kembali issu perbuatan radikalisme yang disebabkan dengan munculnya gerakan-gerakan ISIS yang terus merajalela di beberapa wilayah nusantara, akibatnya bergejolak ancaman terorisme di Poso, dan adanya pencekalan yang berupa penggunaan nama Ali dan Muhammad dibandara yang diidentikkan dengan teroris, terus memperkeruh suasana yang tidak kondusif terhadap kehidupan antar umat beragama di Nusantara (Natalia, 2016).

Pemahaman atau aliran radikalisme akan menjadi peluang terpapar di berbagai kalangan dalam masyarakat. Pada dasarnya diakibat oleh tuntutan perubahan sosial, ekonomi, politik dan militer dengan keinginan tersebut akan mendobrak situasi yang ada menginginkan perubahan secara drastis. Dengan keinginan tersebut maka melakukan dengan cara-cara radikal dan kekerasan serta gerakan-gerakan keagamaan yang berusaha merubah secara total tatanan sosial dan politik yang telah ada dengan cara kekerasan (Yuanda, 2021).

Jika dikaitkan dengan pemboman seperti yang pernah terjadi di Bali misalnya, Amrozi selaku terpidana utama merupakan alumni dari sebuah pesantren yang secara kapasitas intelektualnya tidak mungkin mampu menciptakan bom berdaya ledak tinggi hingga mengakibatkan kerusakan dan korban jiwa yang sanga besar. Diduga bom Amrozi hanyalah sebuah identitas kambing hitam yang sengaja dimunculkan untuk menutupi bom lain yang diledakkan oleh oknum tak bertanggung jawab (Amiruddin, 2014). Terlepas apakah Amrozi pelaku utama atau pion dari pihak tertentu, background-nya 
selaku alumni pesantren adalah masalah sosial tersendiri bagi wordview masyarakat Aceh yang pada umunya berbasis dayah (pesantren).

Tentunya ini adalah pukulan telak dan bahan evaluasi, sejauh mana ternyata peran pesantren dalam mencegah tindakan radikalisme, sudah mampukah pesantren membentengi para santrinya dari pengaruh eksternal, atau malah justru pesantren atau lembaga keagamaan itu sendiri yang menjadi subjek penanam nilai-nilai tercela atau nilai kebencian dengan motif sakral seperti jihad dan sebagainya.

Pada februari tahun 2010 Aceh dikejutkan dengan informasi sebuah tindakan teroris yang melibatkan oknum orang Aceh sebagai pelaku utamanya, hampir semua orang Aceh tidak percaya akan peristiwa tersebut. Di mana-mana terjadi diskusi, mereka menganggap itu merupakan rekayasa pihak tertentu untuk menjelek-jelekkan Aceh. Apalagi beberapa media elektronik sering menyebutkan kata-kata teroris Aceh, yang ternyata setelah dipaparkan namanama yang terlibat, identitas mereka memang tidak bertradisi Aceh. Bahkan tokoh yang disebut-sebut salah satu pimpinan mereka dengan nama tradisi Aceh, Abu Rimba, ternyata tidak bisa berbahasa Aceh. Tetapi bagaimanapun ternyata sejumlah orang yang divonis sebagai terpidana teroris kemudian mengaku sendiri sebagai orang Aceh (Amiruddin, 2004).

Penyebaran buku-buku yang berisi tentang narasi-narasi yang dapat memunculkan inspirasi untuk tindakan radikalisme dan terorisme juga dilakukan secara tersembunyi di Aceh. Buku-buku tersebut ditulis berseri, sangat mungkin juga dikirim mengikuti seri penerbitan tersebut. Itu artinya Aceh dapat menjadi objek wilayah yang memproduksi teroris di masa yang akan datang (Amiruddin, 2003). Begitu juga dengan gerakan terorisme yang sempat eksist di Aceh Besar tepatnya pegunungan Seulawah Aceh. Tidak berjalan dengan maksimal meskipun para pelaku menggunakan azas-azas keislaman dalam merekrut anggotanya. Selogan seperti bahwa Indonesia harusnya memiliki lambang dan dasar negara Islami tidak cukup kuat karena masyarakat Aceh memiliki Ulama Dayah sebagai agen kontrol keagamaan (Saputra, 2019).

Paradigma di atas menunjukkan bahwa pendekatan sosial-religius dengan melibatkan Ulama Dayah merupakan langkah yang strategis dan efektif karena dalam masyarakat telah mempunyai kepercayaan terhadap Ulama bahkan sejak zaman kesultanan yang populer dipanggil sebagai Tengku Dayah, fatwa ulama dayah lebih dominan diaplikasikan oleh rakyat Aceh dibanding 
otoritas yang ditetapkan oleh pemerintah(Nurlaila \& Zulihafnani, 2019). Dengan otoritas ulama dayah diharapkan resolusi konflik dapat cepat terwujud dan diterima semua kelompok sehingga tidak ada lagi konflik laten yang tersembunyi dalam masyarakat.

Maraknya dinamika radikalisme agama, yang akibatnya pada kasus terorisme dengan mengatas namakan agama sehingga berdampak pada kehidupan sosial dalam masyarakat. Kabupaten Aceh Jaya sebagai daerah yang masih kental akan nilai keIslaman dan nilai sosial, oleh karena itu perlu dilestarikan nilai-nilai tersebut agar tetap kondusif melalui peran ulama untuk mencegah pengaruh radikalisme yang dikalangan santri, karena besar kemungkinan paham radikal dapat berkembang pada kalangan santri maupun dalam masyarakat jika tidak diantisipasi, seperti di Aceh Besar tepatnya di gunung selawah sempat eksis gerakan teroris yang mengunakan azas-azas keIslaman akan tetapi gerakan tersebut tidak berjalan dan dapat dihentikan. karena adanya pihak-pihak yang megantisipasi kegiatan tersebut termasuk peran para ulama. Tidak tutup kemungkinan paham radiklisme berkembang dilembaga pendidikan tradisional seperti dayah.

Peran dan strategi ulama dayah menjadi sebuah solusi untuk menangkal paham radikalisme agar masyarakat tidak terpapar dengan paham tersebut, karena tindakan radikalisme akan berdampak pada tindakan teroris. Berdasarkan uraian diatas penulis melakukan sebuah penelitian secara mendalam terhadap strategi ulama dayah dalam menangkal radikalisme di Kabupaten Aceh Jaya.

Ulama Dayah adalah sosok yang sangat penting dalam sosial-religius masyarakat Aceh begitu juga di Aceh Jaya yang mengandalkan pendapatpendapat ulama dalam melakukan praktek ibadah. Radikalisme di Aceh dapat ditekan oleh kebijakan para Ulama Dayah yang menentang terjadinya perang atau kerusuhan sesama muslim, apabila ada gerakan radikal yang berupaya mempengaruhi pemikiran masyarakat (Amiruddin, 2003).

\section{METODE PENELITIAN}

Penelitian ini merupakan penelitian kualitatif, yaitu penelitian yang menghasilkan data secara holistik dalam bentuk kata-kata secara deskriptif tentang fenomena-fenomena atau perilaku-perilaku subjek penelitian yang dapat diamati. Penelitian kualitatif merupakan penelitian yang menghasilkan data 
secara deskriptif dalam bentuk kata-kata, tulisan atau lisan dari partisipan dan perilaku-perilaku yang dapat diamati (Moleong, 2014).

Penelitian ini mendeskripsikan secara mendalam tentang kegiatankegiatan, kejadian-kejadian tentang strategi ulama dayah dalam penangkalan terorisme di kalangan santri berdasarkan fakta alamiah yang terjadi. Penelitian kualitatif diarahkan untuk mendeskripsikan tentang fakta-fakta, gejala-gejala dan kejadian-kejadian secara akurat dan sistematis (Zuriah, 2007). Hasil pengumpulan data yang diperoleh dianalisis dari berbagai keterkaitan partisipan dengan menguraikan makna dari suatu peristiwa atau kejadian. Pemaknaan partisipan dilihat dari keyakinan, ide, pemikiran, perasaan dan kegiatankegiatan yang dilakukan oleh partisipan (Sukmadinata, 2013).

Dengan demikian, maka penelitian ini mengkaji tentang kondisi yang terjadi berkaitan dengan strategi ulama dayah dalam menangkal radikalisme di Kabupaten Aceh Jaya. Tujuan penelitian ini adalah Mendeskripsikan dan menganalisis fenomena-fenomena secara mendalam melalui teknik pengumpulan data.

Subjek dalam penelitian ini adalah ulama dayah, ulama Majelis Permusyawaratan Ulama (MPU) dan santri di Kabupaten Aceh Jaya. Sumber data diperoleh dari data primer dan data sekunder. Data primer didapatkan secara langsung dari beberapa orang ulama dayah, dan beberapa orang santri dayah serta mengobservasi segala sesuatu kegiatan yang dilakukan oleh ulama Kabupaten Aceh Jaya. Data sekunder didapatkan secara tidak langsung di lokasi penelitianu melalui media perantara yang bersumber dari tulisan-tulisan karya ilmiah yang berkaitan dengan ulama, santri, dan radikalisme serta dokumendokumen yang berkaitan dengan fokus penelitian.

Pengumpulan data dilakukan mellaui wawancara, observasi dan dokumentasi. Wawancara dilakukan dengan MPU, ulama dayah dan satri untuk mendapatkan data atau informasi yang berkaitan dengan strategi ulama dayah dalam menangkal radikalisme di Kabupaten Aceh Jaya. Wawancara atau interview merupakan proses interaksi dan komunikasi yang memperhatikan beberapa faktor, yaitu: kondisi pewawancara, responden, topik penelitian yang tertuang dalam daftar pertanyaan dan situasi wawancara (Sukmadinata, 2013). Observasi dilakukan untuk mengumpulkan data melalui pengamatan tentang strategi ulama dayah dalam menangkal radikalisme pada kalangan santri di Aceh Jaya. Penulis mengamati segala sesuatu kegiatan yang dilakukan oleh 
ulama terhadap penangkalan radikalisme dikalangan santri. Pengamatan merupakan perhatian terhadap sesuatu objek dengan menggunakan seluruh indera (Arikunto, 2014). Dokumentasi dilakukan dengan cara mengumpulkan informasi melalui catatan, surat atau bukti terhadap kegiatan ulama dalam melakukan penangkalan radikalisme serta peneliti mencatat dan menulisnya hasil-hasil dari telaahan dokumen tersebut. Dokumen sebagai sumber data yang dapat digunakan untuk menguji, menafsirkan dan mengamalkan (Moleong, 2014).

Analisis data dilakukan secara naratif kualitatif (Sukmadinata, 2013). Data-data yang diperoleh melalui wawancara, observasi dan dokumentasi dianalisis secara sistematis dengan cara mengorganisasikan ke masing-masing fokus penelitian, kemudian melakukan sistesis, memilih data yang penting dan sesuai dengan fokus penelitian, dan membuat kesimpulan. Tahapan analisis data dalam penelitian ini adalah tahap reduksi data, menyajikan data, membuat kesimpulan dan verifikasi (Sugiyono, 2007).

\section{HASIL DAN PEMBAHASAN}

Radikalisme dan terorisme merupakan suatu pemahaman dan tindakan yang tidak dibenarkan dalam Islam, karena Islam merupakan agama yang menebar kasih sayang terhadap umat manusia. Ulama Aceh Jaya sangat mengantisipasi dan melarang kepada masyarakat agar tidak terpapar pahampaham yang mengarah kepada tindakan teroris. Ketua MPU Aceh Jaya mengatakan bahwa salah satu upaya yang dilakukan untuk penangkalan terorisme adalah dengan cara menghimbauan kepada masyarakat agar jika melakukan pengajian agar tidak boleh dilakukan dengan cara tertutup dan pengajian dilakukan secara terbuka kepada masyarakat. Strategi ini dilakukan agar tidak terjadinya fitnah dan tidak beredar paham-paham yang bertentangan dengan ajaran Islam.

Ketua MPU Aceh Jaya dalam menjalankan tanggung jawabnya bekerjasama dengan pihak TNI dan polri untuk mewujdkan masyarakat Aceh Jaya yang makmur dan tentram dalam hal ini ikut memantau aktifitas dalam masyarakat supaya mudah terdeteksi jika ada paham-paham terorisme yang dapat mempengaruhi perilaku masyarakat yang tidak sesuai dengan ajaranajaran islam. Ketua MPU Kabupaten Aceh Jaya sangat aktif dalam menangkal 
paham terorisme di kalangan masyarakat yang bekerjasama dengan pemerintah pemerintah kabupaten, pemerintah gampong dan aparat keamanan.

Keberadaan ulama dayah di tengah-tengah masyarakat sangat penting untuk mengatasi berbagai persoalan yang dihadapi dalam kehidupan masyarakat apalagi saat ini yang sedang terkuaknya isu radikalisme. Dalam perkembangan masyarakat Aceh lembaga pendidikan tradisional dayah telah banyak memberi peran dan fungsinya terhadap masyarakat Aceh sendiri, hal ini dapat dilihat dari sejarah pada masa yang telah lalu ulama selalu menjadi garda terdepan terhadap persoalan yang diahadapi umat dengan memberikan berbagai kontribusinya (Hamdan, 2017). Majelis Ulama Indonesia berperan sebagai wadah silaturrahmi para ulama, musyawarah para ulama, mengayomi umat muslim, mengembangkan dan mengamalkan ajaran agama Islam, wadah pemberi fatwa terkait permasalahan agama Islam serta menjalin persatuan dan kesatuan dalam kehidupan (Ahmatnijar, 2016).

Ketua MPU Aceh Jaya yang merupakan pimpinan dayah Darul Abrar di Kabupaten Aceh Jaya mempunyai beberapa strategi dalam berdakwah untuk mengantisipasi terjadinya radikalisme pada santri. Keberadaan ulama daya di tengah-tengah masyarakat Aceh Jaya juga sebagai tokoh masyarakat. Ulama dayah tidak hanya memahami ilmu agama secara mendalam akan tetapi juga mempunyai wawasan yang luas dan memiliki peran dan strategi dalam berdakwah untuk menangkal tindakan-tindakan yang radikal pada kalangan santri. Adapun strategi-strategi yang dilakukan oleh ulama dayah dalam penangkalan terorisme di Kabupaten Aceh Jaya diuraikan berikut ini.

\section{Penguatan materi wawasan kebangsaan}

Santri yang mondok di dayah Darul Abrar di desa Sayeung Kecamatan Setia Bakti kabupaten Aceh Jaya tidak hanya dibekali dengan materi-materi tentang keagamaan akan tetapi mereka juga diajarkan konsep-konsep bahwa manusia sebagai makhluk sosial yang saling menghormati perbedaan antara satu dengan yang lainnya, tatacara hidup yang rukun, mengahargai pendapat dan perbedaan, serta tatacara hidup berbangsa dan bernegara. Wawasan kebangsaan dimulai dari hal-hal sederhana, misalanya mulai dari bahasa dan karakter yang berbeda, tujuannya untuk meminimalisir konflik dan radikal pada kalangan santri yang dilatarbelakangi oleh perbedaan karakter yang ada pada santri. Disamping santri diajarkan untuk saling menerima perbedaan, di dayah juga 
menekankan pemahaman tentang aqidah, sebab pembelajaran atau dakwah utama di dayah adalah mendidik santri agar memahami Islam secara kaffah, damai, toleransi, saling menghormati dan megaplikasikan bentuk-bentuk Islam yang rahmatan lil'alamin di tengah-tengah masyarakat.

Wawasan kebangsaan merupakan wawasan secara nasional yang bersumber dari Undang-Undang dasar 1945 dan Pancasila sebagai cara pandang dan sikap seseorang terhadap dirinya dan lingkungannya untuk menunjang persatuan dan kesatuan bangsa Indonesia. Penerapan wawasan kebangsaan dapat dilihat melalui toleransi (tasamuh), moderat (tawasuth), seimbang (tawazun) dan amar makruf nahi mungkar (Faizah, 2020)

\section{Penguatan tentang cinta tanah air}

Pimpinan dayah Darul Abrar mengemukakan bahwa beliau menyampaikan pesan dakwah tentang menumbuhkan sikap cinta tanah air dan nasionalisme kepada santri dan dewan guru. Strategi ini dilakukan untuk mengantisipasi terjadinya tindakan radikalisme dikalangan santri dan di masyarakat. Strategi dakwah yang dilakukan oleh ulama Aceh Jaya tidak hanya berfokus pada konteks keagamaan saja, akan tetapi juga menyampaikan pesanpesan dakwah yang mempersatukan umat dan tentu ini menjadi sebagai strategi dalam rangka mempersatukan berbagai yang latar belakang berbeda.

Upaya lain yang dilakukan oleh ulama dayah di Aceh Jaya untuk menangantisipasi terjadinya gejala radikalisme yaitu dengan berdakwah di tengah masyarakat agar mengaplikasikan ajaran agama Islam sebagai agama yang membawa rahmat bagi seluruh alam melalui perilaku saling menjaga persatuan, tidak berpecah belah sesama bangsa apalagi se-akidah. Ulama dayah juga melakukan kerjasama dengan berbagai pihak untuk mendukung penanman sikap cinta tanah air kepada santri.

Cinta tanah air adalah sikap atau karakter yang wajib dimiliki oleh setiap warga negara Indonesia yang berkaitan dengan hak dan kewajibannya sebagai warga negara serta ikut dalam membela negara. Penanaman nilai-nilai karakter cinta tanah air dapat berdampak pada kehidupan sehari-hari santri dalam menjalani kehidupannya dan berinteraksi denga masyarakat di lingkungannya (Arif, 2018). 


\section{Melakukan kerjasama dengan TNI dan Polri}

Ulama dayah mendorong pihak-pihak barbinsa untuk terus bekerjasama dalam membangun daerah Kabupaten Aceh Jaya yang kondusif serta memantau kegaiatan-kegiatan dalam masyarakat supaya masyarakat tidak terpengaruh dengan paham-paham yang radikalisme. Ulama dayah mengemukakan bahwa jika tidak diantisipasi yang dimulai dari kalangan masyarakat maka akan sulit dicegah tindakan-tindakan radikal pada kalangan santri, karena masyarakat merupakan bagian dari orang tua para santri. Aparat keamanan di daerah terus memantau keadaan dalam masyarakat agar tidak terjadinya kelompokkelompok radikalisme dan teroris. Ketua MPU Aceh Jaya juga secara aktif mendorong masyarakat agar bekerjasama dalam hal penangkalan radiklisme mulai di desa dan kota.

Kerjasama dilakukan dengan tujuan agar semua pihak saling berkoordinasi, saling menjaga dan memiliki persamaan persepsi bahwa radikalisme dan terorisme tidak boleh ada di Indonesia dan harus diberantas sampai apada akarnya sehingga keutuhan, persatuan dan kesatuan bangsa Indonesia tetap terjaga sebagaimana tujuan para pendiri dan pahlawan bangsa Indonesia. Kerjasama dayah dengan pemerintah, orang tua santri, donatur dan masyarakat dapat diperluas dalam menunjang pendidikan, pembangunan sarana dan prasarana, dan pemeriharaan aset dayah (Prayoga \& Jahari, 2019).

\section{Membiasakan sikap keteladanan}

Ulama dayah mewajibkan para teungku (guru) agar memliki akhlak dan sikap yang teladan. Hal ini dikenakan perilaku teungku merupakan model yang akan ditiru oleh santri dan menjadi teladan. Teungku dayah sebagai pendakwah tidak boleh berkata kasar apalagi bertindak kasar dalam berinteraksi diruang lingkup dayah dan di lingkungan masyarakat sehingga harus selalu mengedepankan akhlak yang mulia, disiplin, sikap yang toleransi, saling menghargai dan jujur, kemudian rendah hati, dan tidak sombong. Dengan adanya dakwah melalui perbuatan yang dilakukan oleh Teungku dayah maka santri akan mengikuti sikap-sikap yang sering dilihat dan dipraktikkan di lingkungannya. Keteladaan dari ulama dayah dan teungku dayah diharapkan dapat menjadi model bagi santri sehingga jauh dari tindakan radikalisme. 


\section{Penguatan melalui proses pengajian kitab kuning}

Pimpian dayah Ibrahiiyah Tenom sebagai salah satu ulama di Aceh Jaya, strategi beliau dalam menangkal radikalisme pada kalangan santri seperti pemberian pemahaman agama kepada santri yang baik dan benar, agar santri benar-benar berprilaku yang baik dan tidak radikal. Dalam menangkal tindakantindakan radikal pada kalangan santri. Pimpinan dayah budi Ibrahimayah Teunom mendidik santri dengan memberikan pengetahuan agama agar santri memahami agama Islam dengan benar dan memiliki perilaku yang sesuai dengan ajaran Islam, seperti membina akhlak melalui pengajian-pengajian didayah.

Penanaman aqidah Islam menjadi pokok dasar dalam proses pembinaan santri karena santri yang berasal dari orang tua masih kurang memahami agama, maka di dayah mereka didik dengan benar agar nantinya menjadi masyarakat yang tidak radikal. Penenaman nilai-nilai akhlak dapat dilakukan melalui proses pengajian secara terpadu atau terintegrasi di dayah. Guru sebagai model dan agen perubahan santri harus menjadi teladan dan dapat memberikan contohcontoh teladan melalui kehidupan para nabi, para sahabat nabi, para ulama dan kisah-kisah lainnya yang mengandung makna dari nilai-nilai kemanusian dan religius sesuai dengan tujuan pengajian (Hasnadi et al., 2020). Hal yang menjadi dasar pembelajaran dasar bagi santri meliputi penanaman tauhid, rukun iman, rukun Islam, dengan tujuan mencegah prilaku syirik, tahyul dan bid'ah di kalangan santri .

\section{Kegiatan menghafal Al-Qur'an}

Santri yang mondok di dayah Darul Abrar mereka dibiasakan menghafal Al- qur'an melaksanakan shalat isya secara berjamaah dan mengikuti aktifitas pengajian kitab kuning dan kitab tafsir. Melalui konsep-konsep yang bersumber dari kitab kuning tersebut membahas tentang akhlak yang baik. Dengan adanya kegiatan pengajian dan menghafal Al-Qur'an di dayah maka akan dapat memberikan pemahaman kepada santri terkait ilmu keislaman. Selain itu tujuan dari program menghafal dan pengajian ini agar dapat tertanam nilai-nilai karakter yang baik dan beriman terhadap terhadap santri. 


\section{Kegiatan keagamaan di dayah}

Santri dayah Darul Abrar dibekali dengan kegiatan-kegiatan keagamaan di komplek dayah. Kegiatan keagamaan bukan hanya dalam bentuk ibadah wajib saja akan tetapi juga kegiatan keagamaan lainnya, seperti shalat zhuha, praktek shalat mayit, dan kegiatan memperingati hari besar Islam (PHBI) yang dilaksanakan di dayah Darul Abrar pada setiap setahun sekali, misalnya memperingati tahun baru Islam 1 (satu) Muharram, kegiatan maulid Nabi, tujuannya adalah supaya santri terbiasa dengan kegiatan keagamaan dan menjadi warga negara yang baik, taat pada agama dan patuh pada negara.

Aktifitas memperingati maulid Nabi ini dilaksanakan pada setiap tahun sekali setiap bertepatan dengan kelahiran Nabi Muhammad SAW. Pada kebiasaannya kegiatan tersebut dilaksanakan dengan semarak, selain adanya kanduri, makan bersama dan bersedekah, ada juga kegiatan lomba, kegiatan ceramah agama. Maksud dan tujuan dari memperingati maulid Nabi agar santri dapat memahami dengan benar kegiatan-kegiatan keagamaan selain itu untuk mengenang perjuangan Nabi Muhammad SAW dalam berdakwah untuk memperbaiki akhlak manusia diatas permukaan bumi ini.

Dengan adanya ceramah keagamaan santri terus mendalami tentang pengetahuan keIslaman seperti adanya kisah-kisah keteladanan Nabi, akhlak Nabi, selain itu agar santri memahami makna dari memperingati hari lahir Nabi, dengan dibekali berbagai kegiatan keagamaan dan narasi yang positif diharapkan dapat membentuk cara berpikir dan sikap para santri sehingga tidak mudah terpapar oleh paham-paham yang radikalisme dan terorisme.

Dayah merupakan salah satu tempat yang tepat dalam pembentukan akhlak para santri dan memiliki peran, fungsi serta tanggungjawab dalam penangkalan radikalisme di kalangan santri. Internalisasi nilai-nilai cinta tanah air, menghargai sesama manusia yang dilakukan di lingkungan dayah dapat menjadi kebiasaan santri sehingga menjadi sikap yang dapat menangkal radikalisme. Penananaman wawasan kebangsaaan dan nilai-nilai karakter di lingkungan dayah harus menjadi kebiasaaan dan dikembangkan berdasarkan kearifan lokal yang dilakukan secara sistematis, menyeluruh, dan integratif. Kegiatan-kegiatan keagamaan yang dilakukan di antaranya: budaya membaca al-quran, berdoa ketika memulai dan mengakhiri pengajian, disiplin, budaya bersih, jujur, kegiatan dalam rangka memperingati hari besar Islam (Hasnadi, 2019). 


\section{KESIMPULAN}

Kabupaten Aceh Jaya termasuk salah satu daerah yang belum terdapat tindakan-tindakan radikalisme yang mengatasnamakan agama dalam masyarakat yang tujuannya kepada tindakan teroris, kehidupan masyarakat didaerah tersebut masih sangat kondusif. Dalam hal ini tidak terlepas konsistensi dan sinergisitas semua elemen baik pemerintah, tokoh agama maupun tokoh adat sehingga masyarakat tidak terpapar paham radikalisme dan terorisme.

Ulama dayah di Kabupaten Aceh Jaya memiliki peran penting terhadap persoalan dalam masyarakat, terutama mereka sebagai pemimpin dayah yang secara terus menerus melakukan dakwahnya kepada santri sehingga melahirkan santri anti radikal dan anti teroris. Berbagai strategi dan upaya penangkalan radikalisme yang dilakukan oleh ulama dayah di Aceh Jaya merupakan salah satu bentuk kontribusi dan kepeduliannya terhadap bangsa dan Negara.

Penangkalan radikalisme pada kalangan santri sangat penting untuk dilakukan setiap teungku di dayah agar satri tidak terlibat dalam perbuatanperbuatan yang mengarah kepada terorisme. Peran ulama dayah sangat penting dalam mendidik santri dengan baik dan benar sehingga para santri menjadi kader ulama yang mengamalkan ajaran Islam secara kaffah. Dengan demikian, penelitian berikutnya sangat diharapkan untuk mengkaji secara mendalam tentang penangkalan sikap radikalisme dan aspek kajian lainnya di kalangan santri pada tempat dan lokasi yang berbeda. 


\section{DAFTAR PUSTAKA}

Ahmatnijar, A. (2016). Ulama berbagi otoritas: fungsi dan peran MUI Kota Padangsidimpuan dalam meningkatkan kesadaran dan budaya hukum masyarakat. Tazkir: Jurnal Penelitian Ilmu-Ilmu Sosial Dan Keislaman, https://doi.org/10.24952/tazkir.v1i2.368. 2(1), 143-158.

Amiruddin, M. H. (2003). Pengawal Agama Masyarakat Aceh. Lhokseumawe: Nadiya Foundation.

Amiruddin, M. H. (2004). Perjuangan Ulama Aceh di Tengah Konflik. Yogyakarta: Cenninets Press.

Amiruddin, M. H. (2014). Isu Terorisme dan Respons Aktivis Muda Aceh. Walisongo: Jurnal Penelitian Sosial Keagamaan, https://journal.walisongo.ac.id/index.php/walisongo/article/view/256. 22 (1), 25-38.

Arif, M. (2018). Revitalisasi Pendidikan Cinta Tanah Air di Pondok Pesantren Darul Ihsan Menganti Gresik. Jurnal Iqra': Kajian Ilmu Pendidikan, https://journal.iaimnumetrolampung.ac.id/index.php/ji/article/view/369. 3(2), 277-296.

Faizah, R. (2020). Penguatan Wawasan Kebangsaan dan Moderasi Islam Untuk Generasi Millenial. Jurnal PROGRESS: Wahana Kreativitas Dan Intelektualitas, http://dx.doi.org/10.31942/pgrs.v8i1.3442. 8(1), 38-61.

Hamdan, H. (2017). Dayah Dalam Perspektif Perubahan Sosial. AL-HIKMAH: Media Dakwah, Komunikasi, Sosial Dan Budaya, https://doi.org/10.32505/hikmah.v8i1.402. 8(1).

Hasnadi, Asiah, N., \& Fatimahwati. (2020). School Management in the Implementation of Character Values in the Teaching-Learning Process BT Proceedings of the 1st Progress in Social Science, Humanities and Education Research Symposium (PSSHERS 2019). 645-648. https://doi.org/https://doi.org/10.2991/assehr.k.200824.147

Hasnadi, H. (2019). Penerapan Nilai-Nilai Karakter Melalui Budaya Sekolah. Idarah (Jurnal Pendidikan Dan Kependidikan), https://doi.org/10.47766/idarah.v3i2.562.3(2), 56-70.

Moleong, L. J. (2014). Metodologi Penelitian Kualitatif. Bandung: Remaja Rosdakarya.

Natalia, A. (2016). Faktor-faktor Penyebab Radikalisme dalam Beragama (Kajian 
Sosiologi terhadap Pluralisme Agama di Indonesia). Al-Adyan: Jurnal Studi Lintas Agama, http://www.ejournal.radenintan.ac.id/index.php/alAdyan/article/view/143. 11(1), 36-56.

Nurlaila, N., \& Zulihafnani, Z. (2019). Pengaruh Fatwa Ulama Dayah dalam Masyarakat Aceh. Substantia: Jurnal Ilmu-Ilmu Ushuluddin, http://dx.doi.org/10.22373/substantia.v21i2.3742. 21(2), 93-103.

Prayoga, A., \& Jahari, J. (2019). Manajemen Jejaring Kerjasama Pondok Pesantren. AL MA'ARIEF: Jurnal Pendidikan Sosial Dan Budaya, https://doi.org/10.35905/almaarief.v1i2.1107. 1(2), 81-88.

Saputra, H. (2019). Efektivitas Kearifan Lokal dalam Menangkal Radikalisme di Aceh. LP2M-Universitas Islam Negeri (UIN) Ar-Raniry.

Sugiyono. (2007). Metode Penelitian Kualitatif. Bandung: Alfabeta.

Suharsimi Arikunto. (2014). Prosedur Penelitian, suatu Pendekatan Praktek. Rineka Cipta.

Sukmadinata, N. S. (2013). Metode Penelitian Pendidikan. Bandung: Remaja Rosda Karya.

Yuanda, I. R. (2021). Peran Dayah dalam Menangkal Radikalisme (Studi Kasus pada Dayah Darurrahmah Kota Fajar Kabupaten Aceh Selatan). Jurnal Ilmiah Mahasiswa Fakultas Ilmu Sosial \& Ilmu Politik, http://www.jim.unsyiah.ac.id/FISIP/article/view/16983. 6(2).

Zuriah, N. (2007). Metodologi Penelitian Sosial dan Pendidikan: Teori dan Aplikasi. Jakarta: Bumi Aksara. 